Citation: Puthillam, A. \& Karandikar, S. (in press). Watching Digsustedly? Game of Thrones and Disgust Sensitivity. Psychological Reports.

\title{
Watching disgustedly? Game of Thrones and Disgust Sensitivity
}

Arathy Puthillam, Sampada Karandikar

Monk Prayogshala

\begin{abstract}
Author Note
This manuscript has been accepted for publication. However, the final version of the manuscript will include slight modifications from the current version.
\end{abstract}

Arathy Puthillam, Senior Research Assistant, Department of Psychology, Monk Prayogshala, ORCiD: https://orcid.org/0000-0003-2426-8362;

Sampada Karandikar, Research Author, Department of Psychology, Monk Prayogshala, ORCiD: https://orcid.org/0000-0003-3082-4468.

Declarations of interest: None

This research did not receive any specific grant from funding agencies in the public, commercial, or not-for-profit sectors.

Correspondence concerning this article should be addressed to Arathy Puthillam, Department of Psychology, Monk Prayogshala (Sec 8), 4114, C Wing, Oberoi Garden Estates, Powai, Mumbai 400072, Maharashtra, India.

E-mail: ar@monkprayogshala.in 
Acknowledgements: We thank Hansika Kapoor for comments on this manuscript.

The data and materials that support the findings of this study are openly available in the repository of the Open Science Foundation at http://doi.org/10.17605/OSF.IO/QWFEA, retrieved from: osf.io/qwfea. 


\begin{abstract}
The HBO show Game of Thrones is fascinating, because despite many of its plot points involving the elicitation of disgust, an emotion associated with avoidance behaviors, its viewership has only surged. We explore the relationship between disgust sensitivity and perception of scenes involving moral, sexual, and pathogen disgust in the show by providing participants with descriptions of such scenes. Participants included those who had never seen the show, those who had seen the show at least once, and those who had seen the show multiple times. We found that those who had watched the show once rated the scenes as less disgusting (overall and for moral and sexual disgust) than those who had not. We also investigated sex differences in disgust and found that women rated the scenes as more aversive than men, especially those involving moral and sexual disgust. Finally, those with more opposite sex siblings were more repulsed by the scenes, especially those involving sexual disgust. The present study adds to a long list of studies that analyses popular culture from an adaptive lens and adds to the notion that popular culture is a 'cultural remain' of the evolved human mind.
\end{abstract}

Keywords: Game of Thrones; disgust; evolutionary psychology; emotion; moral disgust; sexual disgust 


\section{Watching disgustedly? Game of Thrones and Disgust Sensitivity}

Disgust is an emotional response to something unpleasant that may lead to rejecting the source of the stimulus (Ekman, 1999). It tends to have distinguished physiological and psychological manifestations in the form of nausea and revulsion respectively (Rozin \& Fallon, 1987). While most early theories of disgust have focused on ingestion of harmful substances, including bodily wastes of human and animals (Angyal, 1941; Ekman \& Friesen, 1975; Rozin \& Fallon, 1987), more recent theories have proposed that disgust could be elicited by the need to evade other harmful behaviors, such as avoiding the cost related to unwanted sexual contact (Fessler \& Navarrete, 2004), and social transgressions such as norm violations (Kurzban et al., 2007). Thus, disgust has been proposed to have evolved to solve three functionally distinct adaptive problems: fitness cost of infectious agents (Pathogen Disgust); fitness costs related to maladaptive or risky sexual behaviors (Sexual Disgust); and fitness costs related to social transgressions (Tybur et al., 2009, 2013).

Pathogen disgust serves as a first line of defense against pathogen infection. A reliable detection of pathogen presence could be done through perceptual systems, such as visual cues (Giovannoni, 2001), texture (e.g., Curtis et al., 2011), or smell (e.g., Curtis \& Biran, 2001). Since a false alarm has relatively little cost compared to a false negative, the threshold for acting on ambiguous cues related to disgust is low (Tybur et al., 2013). The reaction to coming close to a disgust elicitor includes physical avoidance (Roseman et al., 1994), including avoidance or stigmatization of the disgust-invoking individual (Oaten et al., 2009) or the group (Faulkner et al., 2004).

Sexual disgust involves "avoidance and rejection of sexual contact with those whose sexual value was relatively low among the potential pool of mates" (Tybur et al., 2013, p. 72). This includes behaviors like incest-avoidance (Fessler \& Navarrete, 2004; Lieberman et al., 2007; 
Park \& Schaller, 2005), as well as assessing mate quality (Buss, 1989; Rhodes et al., 2003; Thornhill \& Gangestad, 1999).

Women tend to be more easily disgusted than men, in that they experience elevated sexual and pathogen disgust. Women are more likely to contract Sexually Transmitted Infections (Centers for Disease Control and Prevention, 2008), and have a higher minimum parental investment (e.g., Buss \& Schmitt, 1993; Trivers, 1972), implying that they have more to lose by being indiscriminate in their sexual encounters. Thus, sexually risky behaviors are likely to be costlier for women than men, and thus, they are more likely to experience higher sexual disgust. Further, they may be averse to pathogens because they affect the fitness of their offspring and facilitate transmission of diseases (Sear \& Mace, 2008). Thus, heightened disgust sensitivity would promote fitness for themselves, their mates, and their offspring (Al-Shawaf et al., 2018).

Sex differences in moral disgust have not yet been established (Al-Shawaf et al., 2018). However, given the fitness costs of social transgressions, women would be likely to experience higher moral disgust as compared to men. Behaviors eliciting pathogen and sexual disgust are often moral issues across cultures (Tybur et al., 2016), while moral disgust includes social transgressions, including non-normative and antisocial acts that inflict cost on other members of one's group, such as lying, harming others, stealing, fraud, and cheating (Tybur et al., 2009, 2013).

Other theorizations of disgust fall in the realm of morality directed towards fostering group cohesion (e.g., the purity/sanctity foundation; (Graham et al., 2011, 2016; Haidt, 2007). Tybur et al. (2009), however, propose an individual-level model, wherein moral disgust activates behaviors to punish as well as avoid social relationships with those who violate group norms. Additionally, in line with the Westermarck hypothesis (1921), incest avoidance is an evolved mechanism to safeguard from inbreeding depression. Proximity to others during the critical years 
of development serves as a kinship cue, which further leads to sexual avoidance behaviors. Accordingly, negative attitudes towards sibling incest are formed due to co-residence or cosocialization with an opposite sex other (Lieberman et al., 2003). This aversion holds true even in third-party contexts, wherein there is a decreased tolerance of others' incestuous behaviors (Fessler \& Navarrete, 2004).

\section{Prolonged Exposure}

Given that disgust is an aversive reaction to unpleasant stimuli, what happens when one encounters it for a lengthened period of time? Prolonged exposure to different types of emotional stimuli often leads to desensitization towards the stimuli. For instance, prolonged exposure to gratuitous and violent feature films instigates and increases hostility (Zillmann \& Weaver, 2006). Similarly, exposure towards sexual media, especially violent sexual media is linked to acceptance of sexual violence and sexual violence myths (e.g., Burgess \& Burpo, 2012); however, it affects men's attitudes more than women's (Rodenhizer \& Edwards, 2017).

Prolonged exposure to disgusting stimuli specifically has also been found to reduce disgust sensitivity (Meunier \& Tolin, 2009; Rozin \& Fallon, 1987). On one hand, it is worth mentioning that desensitization to disgust may be maladaptive. For instance, desensitization to pathogen disgust might lead to ingestion of harmful foods, which threatens one's own, and offsprings' health. Desensitization to moral disgust might be related to engaging in behaviors that cause reputational harm and eventual ostracization. Finally, desensitization to sexual disgust might lead to engaging in sexually harmful behaviors such as indiscrimate sexual relations.

More pertinent to this discussion, however, is that exposure to disgusting stimuli has been successfully employed as an intervention for individuals with high contamination aversion in disgust-based psychopathologies, such as anxiety disorders (Mason \& Richardson, 2012; 
Ojserkis et al., 2018; Taboas et al., 2015). Similarly, graded exposure might be helpful in modification of food aversions (De Silva, 1988).

Moreover, given the inhibitory and excitatory forces of sexual stimuli, there must be an optimum level of disgust sensitivity for healthy sexual interaction. It is possible that arousal may counteract avoidance by lowering the threshold for disgust (de Jong et al., 2013). For instance, sexual arousal has been argued to temporarily reduce disgust elicitation among male students (e.g., Stevenson et al., 2011).

Given the malleability of disgust, we are interested in exploring whether exposure to disgust reduces the extent to which individuals are sensitive to it, within the context of the television show, Game of Thrones.

\section{Game of Thrones}

The show Game of Thrones (Benioff et al., 2011) has had its fair share of violence, gore, and incest. An adaptation of a popular fantasy book series A Song of Ice and Fire (Martin, 1996, 1999, 2000, 2005, 2008), GoT revolves around seven fictional kingdoms and their noble families vying to claim the royal throne. Some of the principal story arcs revolve around incest, treason, murder, physical and sexual assault, and treachery. Despite arousing negative emotions accompanying such acts, it continues to be among the most watched shows on television (Game of Thrones: Season Seven Ratings, 2017; Otterson, 2019). This is especially the case, because many of the scenes in the show are perhaps even designed to evoke shock or disgust. This study aims at exploring disgust-perceptions of GoT viewers within and outside the context of the show. Particularly, the relationships of the three domains of disgust (Pathogen, Sexual, and Moral; (Tybur et al., 2009, 2013) with various disgust-evoking scenes in GoT are explored. 
Stimuli that evoke disgust usually result in avoidance behaviors. We aimed at exploring why despite the plot being driven by disgust-related content, the show's popularity has not wavered at all. Because an avoidance-based construct such as disgust is being assessed in this study, we expect a social desirability bias. Therefore, social desirability would be statistically controlled for. We make the case that exposure to disgusting stimuli, especially within the context of the story, would minimize disgust for the elements of the show, for those who have watched it at least once. Examining GoT from the perspective of research on disgust sensitivity, sex differences within disgust, and the magnitude of exposure to disgusting stimuli, we propose that:

H1: The general disgust score, as measured by the three domain disgust scale (Tybur et al., 2009), would predict the disgust ratings for the scenes in Game of Thrones.

H2A: Participants who have watched the show at least once would rate the scenes as less disgusting than those who have not watched the show at all.

H2B. The higher the number of times people watch the show, the less disgusting they would rate the scenes.

H3. Women would rate the scenes as more disgusting than men, overall.

H4A. Participants with an opposite-sex sibling would rate the scenes depicting sexual disgust as more disgusting.

H4B. Higher number of opposite-sex siblings would correspond with higher disgust ratings for the scenes involving sexual disgust. 


\section{Method}

\section{Participants}

The study has been granted ethical review from the institutional review board at XX XX (\#021018) in January, 2018. The sample comprised 417 participants (135 Indians, and 177 Americans, and 105 belonging to 34 other nationalities; Women=282, Other genders $=9$ ) above 18 years of age $\left(M_{\text {Age }}=25.82\right.$ years, $S D=6.68 ;$ Range $=18-74$ years $)$, all of whom consented to participate in the study. Three hundred and fourteen participants had watched all seasons of GoT at least once. Online sampling and multiple-site entry, as well as snowball sampling was used to collect data. A link to the study was posted on portals such as Psychological Research on the Net.

Further, the form was shared on fan groups of the show on Facebook, Reddit, and on the authors' Twitter handles.

\section{Measures}

All measures, materials, codes, and results are included open access in the following link: XXX

The Three Domain Disgust Scale (Tybur et al., 2009): The scale comprises 21 items $(\alpha=.87$, $M=4.20, S D=.83$ ), seven items each measuring pathogen (e.g., "Stepping on dog poop"; $\alpha=$ $.82, M=4.46, S D=.53$ ), sexual (e.g., "Performing oral sex"; $\alpha=.78, M=3.72, S D=1.08$ ), and moral disgust (e.g., "Deceiving a friend"; $\alpha=.87, M=4.42, S D=.67$ ). This scale was used as a measure of trait disgust sensitivity. Participants rated how disgusting they found the concepts described in the items on a 7-point scale $(1=$ Not at all disgusting; $7=$ Extremely disgusting $)$. Further, a cumulative score of the three disgust types (general disgust) was computed.

Descriptions of scenes (Appendix C) from GoT with (for those who had watched the show) and without (for those who had not watched the show) character names pertaining the three kinds of disgust were compiled by the authors. Twenty-three scenes were described, of which four were 
filler scenes. Six scenes were purported to include moral disgust; nine scenes sexual disgust, and four pathogen disgust. This classification was done by the authors based on the theoretical explanations provided for the three domains of disgust by Tybur and colleagues $(2009,2013)$. This was further verified by five independent raters, who supplemented the domain identification by the authors, by agreeing or disagreeing. Popular scenes that could be easily recalled by those who had seen the show were chosen, based on a discussion by the authors and the raters. Except for one item (see Appendix C), raters agreed upon the a priori classification. Participants were asked to rate, on a scale of 1 (= not at all disgusting) to 7 (= extremely disgusting) how disgusting they found each of the scenes outlined. A Principal Axis Factoring EFA was conducted to validate the model (see Appendix B), the results of which were used to classify the scenes further, and scenes with factor loadings less than .3 were eliminated. For the final analysis, seven scenes were included as moral disgust, seven as sexual, and two as pathogen disgust.

The Balanced Inventory of Desirable Responding Short Form (BIDR-16; Hart et al., 2015). This 16-item scale measured multidimensional social desirability $(\alpha=.76, M=3.88, S D=.70)$, on a 7 -point rating scale $(1=$ Not True to $7=$ Very True $)$.

\section{Procedure}

Participants first entered their demographic details, including whether or not they had watched GoT and how many times had they watched the show. They responded to items regarding the number of opposite-sex siblings they had (response options ranged from 0 to 3 siblings). They then rated how disgusting they found certain scenes in the show. All participants were presented with scenes depicting all three domains of disgust as well as the filler scenes (Appendix C). After this, they were presented with the three-domain disgust scale, followed by the BIDR-16. Participants were debriefed and were provided with details of various helplines they could 
contact in case of distress. They were also told they could quit any time by closing the window if they were uncomfortable, without consequences, and could also withdraw their consent by contacting the authors within two weeks of their participation.

\section{Results}

Descriptive statistics and reliabilities have been presented in the Methods section, and zero-order correlations in Table 1.

[Table 1 near here].

Hierarchical regressions were conducted with the number of opposite-sex siblings, times GoT was seen, age, gender ${ }^{1}$, nationality ${ }^{2}$, and social desirability added as controls (Step 1). The BIDR-16, significantly correlated with trait disgust and its sub-facets. Thus, it was employed as a control to ensure that the results were not confounded by social desirability.

Overall, general trait disgust was a good predictor of general vignette disgust (H1), implying that disgust sensitivity has an effect on how the scenes were perceived, $b=.39, R^{2}=.32, F(409,1)=$ 147.11, $p<.001$ (Figure 1A). This was true of moral, $b=.44, R^{2}=.28, F(1,409)=134.00, p<$ .001 , sexual, $b=.34, R^{2}=.22, F(1,409)=62.49, p<.001$, and pathogen disgust, $b=.16, R^{2}=$ $.14, F(1,410)=62.54, p<.001$. For participants who had watched the show at least once, we found that general trait disgust had a significant robust positive relationship with vignette disgust in the scenes overall, $b=.41, R^{2}=.33, F(1,307)=110.98, p<.001$ (Figure 1B). This was also true of moral, $b=.46, R^{2}=.29, F(1,307)=97.03, p<.001$, sexual, $b=.31, R^{2}=.21, F(1,307)$ $=37.96, p<.001$, and pathogen disgust, $b=.16, R^{2}=.14, F(1,307)=46.07, p<.001$. This was also true for those who had not watched the show (Figure 1C). Specifically, among those who

\footnotetext{
${ }^{1}$ Men $=1$, Women $=2$, Others $=3$

${ }^{2}$ American $=1$, Indians $=2$, Others $=3$
} 
had not seen the show, trait disgust predicted vignette disgust (total: $b=.40, R^{2}=.37, F(2,96)$ $=45.33, p<.001 ;$ moral: $b=.42, R^{2}=.33, \mathrm{~F}(2,96)=44.52, p<.001 ;$ sexual: $b=.44, R^{2}=.33$, $F(2,96)=28.21, p<.001$; pathogen: $\left.b=.13, R^{2}=.14, F(2,96)=12.39, p<.001\right)$.

Further, those who had not watched the show perceived the scenes as significantly more disgusting than those who had $(\mathrm{H} 2 \mathrm{~A}), b=3.57, R^{2}=.08, F(1,410)=4.12, p=.04$. Similar results were found for moral $b=1.96, R^{2}=.05, F(1,410)=4.15, p=.04$, and sexual disgust, $b$ $=2.06, R^{2}=.11, F(1,410)=5.24, p=.02$, but not pathogen disgust, $b=-.45, R^{2}=.01, F(410,1)$ $=1.17, p=.28$, ns. However, the number of times the show was watched did not predict the vignette disgust ratings $(\mathrm{H} 2 \mathrm{~B}), b=-.85, R^{2}=.07, F(1,410)=2.52, p=.11$, ns.

We also explored sex differences in disgust perception of the scenes (H3), and found that women were more disgusted by the scenes than men, overall $b=7.27, R^{2}=.09, F(401,1)=20.30, p<$ .001 , and for moral $b=3.76, R^{2}=.06, F(1,401)=17.96, p<.001$, and sexual $b=3.32, R^{2}=.12$, $F(1,401)=16.02, p<.001$, but not for pathogen vignette disgust $b=.19, R^{2}=.01, F(1,401)=$ $.26, p=.61$.

Further, individuals with opposite sex siblings found the scenes more aversive, overall, than those without opposite sex siblings, $b=2.96, R^{2}=.07, F(1,410)=3.71, p=.05$, as well as those concerning sexual vignette disgust, $b=2.71, R^{2}=.10, F(1,410)=11.86, p<.001(\mathrm{H} 4 \mathrm{~A})$.

Similarly, a higher number of opposite sex siblings predicted a greater level of overall, $b=1.97$, $R^{2}=.07, F(1,410)=6.10, p=.01$, and sexual $b=1.41, R^{2}=.10, F(1,410)=11.98, p<.001$ vignette disgust (H4B).

As an ancillary analysis, we considered items depicting moral vignette disgust, without sexual components (see Supplementary Table 3). Even for such scenes, there was a significant sex difference, in that women rated such scenes as more aversive than men, $b=2.54, R^{2}=.04, F(1$, $401)=12.32, p<.001$ 
Additionally, to test whether trait disgust predicted whether the show was seen (re-coded as $\mathrm{No}=0$, Yes=1), a logistic regression was conducted, controlling for age, gender, nationality, and social desirability. General trait disgust $(b=.01, \mathrm{OR}=1.01, \mathrm{p}=.02)$ and trait pathogen disgust $(b=.05, \mathrm{OR}=1.05, \mathrm{p}=.001)$ predicted the seeing of the show, but trait moral $(b=.02, \mathrm{OR}=1.02, \mathrm{~ns})$ and sexual $(b=-0.0007, \mathrm{OR}=1.00, \mathrm{~ns})$ disgust did not.

\section{Discussion}

This study examined the responses of GoT viewers to various disgust-eliciting scenes from seasons one through seven within the context of moral, sexual, and pathogen disgust (Tybur et al., 2013). Overall, general disgust, and all three domains of disgust predicted how the scenes were perceived. This was also true for those who had seen the show at least once. Thus, the scenes that were aimed at evoking disgust did in fact elicit it. Further, those who were more sensitive to the emotion uniformly found the scenes more disgusting. This also indicated that direct contact with pathogens was not essential to evoke pathogen disgust, meaning it was not necessarily influenced by the medium of exposure. This is in line with previous literature that has used visual primes (e.g., Schaller et al., 2010) or vignettes (White et al., 2013) to evoke pathogen disgust, which also argues that the underlying mechanisms across stimulus types are the same (Tybur et al., 2013, 2014). Sexual disgust is intuitive, even when no rational reasons can be argued (Haidt, 2001), perhaps explaining why the scenes involving sexual disgust did indeed elicit disgust. In addition, all three forms of disgust, considering their social nature (Sherman \& Haidt, 2011), can be argued to dissipate at a higher level of cognition. In other words, as disgust might be processed at a lower level of cognition, it is likely that it is emotionally processed and reacted to, even without a physical stimulus.

We also found that those who had watched the show rated the scenes significantly less disgusting than those who had not. Thus, exposure to disgusting stimuli over a period of time is linked to 
reduced experience of disgust. This implies that even though the scenes elicited a disgust response in general, those who had watched the show perceived the scenes to be less disgusting than those who had not. This might be because of desensitization effects (e.g., Berle, 2007); seeing the show might have desensitized the initial response of disgust among show watchers. This relationship, however, did not hold true for pathogen disgust. This perhaps has implications in the stimulus used. For those who had not watched the show, the only stimuli were the vignettes, which perhaps affected vividness with which the scenes were perceived. Thus, it is probable that visual and vignette-based stimulus share the same underlying cognitive mechanism for pathogen disgust (Tybur et al., 2014), as stated earlier. However, for sexual and moral disgust, a more dynamic stimulus might be required to evoke disgust. Moreover, pathogen disgust was measured with only two scenes, and therefore, floor effects might have affected this finding. Further, the number of times the show was watched was not linked to a significant reduction of the disgust evoked. This is surprising because frequent exposure often leads to desensitization (Mullin \& Linz, 1995). However, it is possible that watching the show even once, considering the shock value of many scenes, might have had a robust impact. For those who had seen the show, the disgust response might have been muted after watching the scenes the first time, whereas for those who had not seen the show, reading the description of the scenes might have been the first time they were exposed to such scenario; this is in line with previous research asserting that desensitization to violent media follows a curvilinear pattern (Fanti et al., 2009). Additionally, emotions such as disgust might be processed below consciousness levels, making us respond to such stimuli quickly, often even at the cost of discrimination (e.g., Öhman, 2008). Thus, the first exposure to such a stimulus might elicit a strong emotional response, negating the need for further exposures. Further, as viewers did not have to actually engage in behaviors that are depicted in the show, this may have impacted how the scenes were perceived. That is, once 
participants watch the show, they might have been accustomed to the scenes, as long as they do not actually have to engage in such behaviors.

Moreover, as expected, female participants rated the scenes as more disgusting than male participants, overall as well as for sexual and moral disgust. However, this was not true of pathogen disgust. This sex difference in sexual disgust might be because of the high parental involvement costs for women (Fleischman, 2014; Trivers, 1972), higher reputational costs for engaging in indiscriminate sexual behaviors (Gallup et al., 2009), and more likeliness to contract STIs (Centers for Disease Control and Prevention, 2008; Seth et al., 2012).

Contrary to previous research (Al-Shawaf et al., 2014; Tybur et al., 2009), we found significant sex differences within moral disgust. This could be because items related to rape loaded on moral disgust, and hence were treated as such. Thus, reputational costs relating to the transgression of moral items, especially those involving sexual violence, might be more evident to female participants, especially in the context of the show. For example, the items "Ramsay physically and mentally assaults Sansa after marrying her" and "Khal Drogo rapes a teenage Daenerys post their marriage" were considered moral disgust. The proportion of women who experience sexual violence and coercion is significantly higher than men, across countries (e.g., Bachman, 1998; ICF, 2017; Rozée, 1993). Besides, women also tend to suffer higher reputational and fitness costs in the face of sexual coercion (McKibbin \& Shackelford, 2011). Therefore, female participants might have been more attuned to the reputational costs to Sansa and Daenerys, and hence for them, more disgust might have been elicited due to the sexual nature of the transgression, compared to male participants. However, even when the items relating to sexual coercion were not included, there was a significant gender difference in disgust towards moral scenes. This might be because other items that loaded on moral disgust, involving social transgressions, also had elements of sexual nature. For example, the item "Tywin Lannister has 
an affair with the prostitute Shae just a while after he has condemned Tyrion of having a relationship with her" and "Shae falsely testifies against Tyrion in court and sleeps with Tywin right after" had content related to prostitution and other facets of sexuality.

Given that they carry their offspring's genes and are likely carriers of pathogens, women also affect the fitness of their partners and offspring, making them highly sensitive to pathogen disgust (see Al-Shawaf et al., 2018 for a detailed discussion). Therefore, it is surprising that women did not rate pathogen disgust as more aversive than men did. This might be because of floor effects, as detailed above.

Finally, participants with opposite sex siblings were more likely to rate the scenes as disgusting, especially those involving sexual disgust, and higher number of opposite sex siblings corresponded with higher disgust. This is in line with the finding that humans have a kinship recognition system (Lieberman et al., 2003, 2007), whereby co-residence with an opposite sexsibling during critical periods early in life is a significant predictor of incest opposition. Accordingly, those who underwent co-socialization have a more aversive reaction to third-party incest. Similarly, those who had more opposite sex siblings are more aversive to third-party incest (Fessler \& Navarrete, 2004).

It has previously been argued that the attraction to such media might be due to associated hedonistic pleasures (Oliver et al., 2007), but also because such media might be thought to offer insights into various taboo aspects of the human condition (Bartsch \& Mares, 2014). The study has implications in further understanding our affinity towards entertainment material that aims to engross us by shocking us. Desensitization has maladaptive effects, as mentioned in the introduction. Subsequently, the implications of repeated consumption of such entertainment are worth exploring. If disgust sensitivity is, in fact, tempered within the context of popular media, the effects of behaviors primed by such media should be interesting. For example, 
desensitization might possibly increase interest in gore-fueled or sexually violent entertainment, including video games, comics, anime, and TV shows, such as Saga, Punisher, Attack on Titan, or Grand Theft Auto. If so, the short- and long-term effects of watching a show featuring aspects of sexual disgust on sexual behaviors merits inquiry. Further, it contributes to our theoretical understanding of emotions in general, and disgust in particular. Considering that disgust sensitivity is an important facet of political attitudes and behaviors (see for example, Inbar et al, 2011, Shook et al, 2017), including distaste of immigrants (Schaller et al., 2015), abortions (Inbar, Pizarro, \& Bloom, 2009), and gay people (Inbar, Pizarro, \& Bloom, 2009; Inbar, Pizarro, Knobe, et al., 2009), there are important practical implications to be considered. For instance, the present study, in examining desensitization, adds to existing literature about combating prejudice through intergroup contact, in that it is possible that disgust towards the outgroup could be reduced by intergroup contact as a form of desensitization. The study also adds to understanding how the same accounts of disgust might be perceived differently by men and women depending on the social costs associated with them.

While the study benefits from novelty, it has certain shortcomings. First, there was a gender imbalance in the sample; however, keeping in mind conservative estimates, ${ }^{3} 81$ participants were required in each group, which we attained. Second, although we did not measure the degree of co-socialization in assessing incest avoidance, it is only part of sexual disgust. This can, however, be considered in future studies. We also did not anticipate participants to have more than three opposite sex siblings. However, this could be a possibility and should be explored. Third, we measured the exposure to disgusting stimuli through verbal descriptions of the scenes, instead of actually exposing participants to the scenes through video clips, which might have

\footnotetext{
${ }^{3}$ Sample size was calculated based on power of .9, a significance level of .01, and an effect size of .40, using the "pwr" package in R.
} 
affected the difference in responses between viewers and non-viewers. This also means that as the study was not experimental, other explanations for the findings are possible. For instance, it may be that those who are highly averse to gore and disgust do not watch such shows because of the high level of such content. However, our ancillary analysis indicated that those who were more averse to general and pathogen (but not moral and sexual) disgust were still likely to watch the show. This might make sense given that even if one is highly sensitive towards pathogen disgust, they are not directly exposed to pathogens through the show, thereby lowering the overall impact of pathogen disgust on watching the show. Moreover, the instances of scenes involving pathogen disgust were fewer. Additionally, verbal descriptions were primarily used to keep the study duration short, as increased duration due to video clips may have increased fatigue among participants. As the participants completed the study online, in various non-lab settings, their motivation to complete the study may have been hampered, if made to watch extended scenes. However, future research could use video clips in conducive settings to measure the differences in mediated exposure to stimuli, versus direct exposure. In the future, experimental work also needs to be conducted to test how sensitization towards disgust occurs through popular media. Fourth, the study was advertised as having to do with the show, and therefore, the sample was self-selected. This may have had an influence on the conclusions drawn. Fifth, the number of items involving pathogen disgust and non-sexual moral disgust were fairly few. However, this was because only memorable scenes were selected and only those vignettes were retained which loaded on one factor or the other. Future research could explore other scenes from this and other shows to investigate this further. As the number of times the show was seen increased, the disgust experienced did not reduce. This is an important finding. Thus, other variables could have also affected the results. For instance, it is likely that culture affects the way certain forms of disgust are experienced (our supplementary analyses indicated that Americans tend to report higher moral disgust than other nationalities and that Indians 
report higher pathogen disgust than other nationalities, for example; Supplementary Table 1); future studies can test for such a cultural difference. Alternative explanations are also possible; for example, there was a ceiling effect for moral disgust (see Supplementary Figure 1). The extent to which participants emotionally processed the materials could also have affected the extent to which disgust was perceived. Future studies should explore such variables.

Various forms of popular culture have been analyzed from an evolutionary perspective (Boyd et al., 2010; Cox \& Fisher, 2009; Grodal, 2004). A majority of the studies exploring imaginative cultures through an evolutionary lens view them as an adaptation, an expectation, a meme, or as utilizing a gene-culture coevolution framework (Saad, 2012). Keeping this in mind, the present study acknowledges that popular culture can be interpreted as cultural remains, comprising universal themes that sheds light on certain features of the evolved human mind. This study, to the best of our knowledge, is the first to explore the link between popular culture and disgust, a universal emotion, using quantitative tools.

\section{Conclusion}

In sum, we contextualized previous research on disgust (Tybur et al., 2009, 2013) through the popular HBO show Game of Thrones. Despite many revolting scenes involving all three forms of disgust, the show's popularity has escalated through its run (Otterson, 2019). Thus, we investigated the link between the three domains of disgust with various disgust inducing scenes in GoT. All in all, it may be concluded that popular culture does not exist outside of biology. 


\section{References}

Al-Shawaf, L., Lewis, D. M. G., \& Buss, D. M. (2014). Disgust and mating strategy. Evolution and Human Behavior, 36(3), 199-205. https://doi.org/10.1016/j.evolhumbehav.2014.11.003

Al-Shawaf, L., Lewis, D. M. G., \& Buss, D. M. (2018). Sex Differences in disgust: why are women more easily disgusted than men? Emotion Review, 10(2), 149-160. https://doi.org/10.1177/1754073917709940

Angyal, A. (1941). Disgust and related aversions. The Journal of Abnormal and Social Psychology, 36(3), 393-412. https://doi.org/10.1037/h0058254

Bachman, R. (1998). Incidence rates of violence against women: A comparison of the redesigned National Crime Victimization Survey and the 1985 National Family Violence Survey. Harrisburg, PA: VAWnet, a project of the National Resource Center on Domestic Violence/Pennsylvania Coalition Against Domestic Violence.

Bartsch, A., \& Mares, M.-L. (2014). Making sense of violence: Perceived meaningfulness as a predictor of audience interest in violent media content. Journal of Communication, 64(5), 956-976. https://doi.org/10.1111/jcom.12112

Benioff, D., Weiss, D. B., \& Cogman, B. (2011). Game of thrones. Home Box Office, Incorporated.

Berle, D. (2007). Graded exposure therapy for long-standing disgust-related cockroach avoidance in an older male. Clinical Case Studies, 6(4), 339-347. https://doi.org/10.1177/1534650106288965

Boyd, B., Carroll, J., \& Gottschall, J. (2010). Evolution, literature, and film: A reader. Columbia University Press.

Burgess, M. C. R., \& Burpo, S. (2012). The effect of music videos on college students' perceptions of rape. College Student Journal, 46(4), 748-763. 
Buss, D. M. (1989). Sex differences in human mate preferences: Evolutionary hypotheses tested in 37 cultures. Behavioral and Brain Sciences, 12, 1-14.

https://doi.org/10.1017/S0140525X00023992

Buss, D. M., \& Schmitt, D. P. (1993). Sexual strategies theory: An evolutionary perspective on human mating. Psychological Review, 100(2), 204. https://doi.org/10.1037/0033295X.100.2.204

Centers for Disease Control and Prevention. (2008). Sexually Transmitted Disease Surveillance, 2008. Atlanta, GA: U.S. Department of Health and Human Services; November 2009.

Cox, A., \& Fisher, M. (2009). The Texas billionaire's pregnant bride: An evolutionary interpretation of romance fiction titles. Journal of Social, Evolutionary, and Cultural Psychology, 3(4), 386-401. https://doi.org/10.1037/h0099308

Curtis, V., \& Biran, A. (2001). Dirt, disgust, and disease: Is hygiene in our genes? Perspectives in Biology and Medicine, 44(1), 17-31. https://doi.org/10.1353/pbm.2001.0001

Curtis, V., de Barra, M., \& Aunger, R. (2011). Disgust as an adaptive system for disease avoidance behaviour. Philosophical Transactions of the Royal Society B: Biological Sciences, 366(1563), 389-401. https://doi.org/10.1098/rstb.2010.0117

de Jong, P. J., van Overveld, M., \& Borg, C. (2013). Giving in to arousal or staying stuck in disgust? Disgust-based mechanisms in sex and sexual dysfunction. Journal of Sex Research, 50(3-4), 247-262. https://doi.org/10.1080/00224499.2012.746280

De Silva, P. (1988). The modification of human food aversions: A preliminary study. Journal of Behavior Therapy and Experimental Psychiatry, 19(3), 217-220. https://doi.org/10.1016/0005-7916(88)90044-4

Ekman, P. (1999). Basic Emotions. In T. Dalgleish \& M. Power (Eds.), Handbook of Cognition and Emotion. John Wiley \& Sons, Ltd. 
Ekman, P., \& Friesen, W. V. (1975). Unmasking the face: A guide to recognizing emotions from facial cues. Prentice Hall.

Fanti, K. A., Vanman, E., Henrich, C. C., \& Avraamides, M. N. (2009). Desensitization to media violence over a short period of time. Aggressive Behavior, 35(2), 179-187. https://doi.org/10.1002/ab.20295

Faulkner, J., Schaller, M., Park, J. H., \& Duncan, L. A. (2004). Evolved disease-avoidance mechanisms and contemporary xenophobic attitudes. Group Processes \& Intergroup Relations, 7(4), 333-353. https://doi.org/10.1177/1368430204046142

Fessler, D. M. T., \& Navarrete, D. (2004). Third-party attitudes toward sibling incest: evidence for Westermarck's hypotheses. Evolution and Human Behavior, 25, 277-294. https://doi.org/10.1016/j.evolhumbehav.2004.05.004

Fleischman, D. S. (2014). Women's disgust adaptations. In Evolutionary Perspectives on Human Sexual Psychology and Behavior (pp. 277-296). https://doi.org/10.1007/978-1-49390314-6_15

Gallup, A. C., O’Brien, D. T., White, D. D., \& Wilson, D. S. (2009). Peer victimization in adolescence has different effects on the sexual behavior of male and female college students. Personality and Individual Differences, 46(5-6), 611-615. https://doi.org/10.1016/j.paid.2008.12.018

Game of Thrones: Season Seven Ratings. (2017). TV Series Finale. https://tvseriesfinale.com/tvshow/game-of-thrones-season-seven-ratings/

Giovannoni, J. (2001). Molecular biology of fruit maturation and ripening. Annual Review of Plant Biology, 52, 725-749. https://doi.org/10.1146/annurev.arplant.52.1.725

Graham, J., Haidt, J., Motyl, M., Meindl, P., Iskiwitch, C., \& Mooijman, M. (2016). Moral Foundations Theory: On the advantages of moral pluralism over moral monism. In The Atlas of Moral Psychology: Mapping Good and Evil in the Mind. 
Graham, J., Nosek, B. A., Haidt, J., Iyer, R., Koleva, S., \& Ditto, P. H. (2011). Mapping the moral domain. Journal of Personality and Social Psychology, 101(2), 366-385. https://doi.org/10.1037/a0021847

Grodal, T. (2004). Love and desire in the cinema. Cinema Journal, 43(2), 26-46.

Haidt, J. (2001). The emotional dog and its rational tail: A social intuitionist approach to moral judgment. Psychological Review, 108(4), 814-834. https://doi.org/10.1037/0033295X.108.4.814

Haidt, J. (2007). The new synthesis in moral psychology. Science, 316(5827), 998-1002. https://doi.org/10.1126/science.1137651

Hart, C. M., Ritchie, T. D., Hepper, E. G., \& Gebauer, J. E. (2015). The Balanced Inventory of Desirable Responding short form (BIDR-16). SAGE Open, 5(4), https://doi.org/10.1177/2158244015621113

International Institute for Population Sciences (IIPS) and ICF. 2017. National Family Health Survey (NFHS-4), 2015-16: India. Mumbai: IIPS.

Inbar, Y., Pizarro, D. A., \& Bloom, P. (2009). Conservatives are more easily disgusted than liberals. Cognition \& Emotion, 23(4), 714-725. https://doi.org/:10.1080/02699930802110007

Inbar, Y., Pizarro, D. A., Knobe, J., \& Bloom, P. (2009). Disgust sensitivity predicts intuitive disapproval of gays. Emotion, 9(3), 435-439. https://doi.org/10.1037/a0015960

Kurzban, R., DeScioli, P., \& O’Brien, E. (2007). Audience effects on moralistic punishment. Evolution and Human Behavior, 28(2), 75-84. https://doi.org/j.evolhumbehav.2006.06.001

Lieberman, D., Tooby, J., \& Cosmides, L. (2003). Does morality have a biological basis? An empirical test of the factors governing moral sentiments relating to incest. Proceedings. Biological sciences, 270(1517), 819-826. https://doi.org/10.1098/rspb.2002.2290 
Lieberman, D., Tooby, J., \& Cosmides, L. (2007). The architecture of human kin detection. Nature, 445, 727-731. https://doi.org/0.1038/nature05510

Martin, G. R. R. (1996). A game of thrones. New York: Bantam Books.

Martin, G. R. R. (1999). A clash of kings. New York: Bantam Books.

Martin, G. R. R. (2000). A storm of swords. New York: Bantam Books.

Martin, G. R. R. (2005). A feast for crows. New York: Bantam Books.

Martin, G. R. R. (2008). A dance with dragons. New York: Bantam Books.

Mason, E. C., \& Richardson, R. (2012). Treating disgust in anxiety disorders. Clinical Psychology: Science and Practice, 19(2), 180-194. https://doi.org/10.1111/j.14682850.2012.01282.x

McKibbin, W. F., \& Shackelford, T. K. (2011). Women's avoidance of rape. Aggression and Violent Behavior, 16(5), 437-443. https://doi.org/10.1016/j.avb.2011.03.010

Meunier, S. A., \& Tolin, D. F. (2009). The treatment of disgust. In B. O. Olatunji \& D. McKay (Eds.), Disgust and Its Disorders: Theory, Assessment, and Treatment Implications. American Psychological Association.

Mullin, C. R., \& Linz, D. (1995). Desensitization and resensitization to violence against women: Effects of exposure to sexually violent films on judgments of domestic violence victims. Journal of Personality and Social Psychology, 69(3), 449-459. https://doi.org/10.1037//0022-3514.69.3.449

Oaten, M., Stevenson, R. J., \& Case, T. I. (2009). Disgust as a disease-avoidance mechanism. Psychological Bulletin, 135(2), 303-321. https://doi.org/10.1037/a0014823

Öhman, A. (2008). Fear and anxiety: Overlaps and dissociations. In M. Lewis, J. M. HavilandJones, \& L. F. Barrett (Eds.), Handbook of emotions (p. 709-728). The Guilford Press.

Ojserkis, R., McKay, D., \& Lebeaut, A. (2018). Associations between mental contamination, disgust, and obsessive-compulsive symptoms in the context of trauma. Journal of 
Obsessive-Compulsive and Related Disorders, 17, 23-30.

https://doi.org/10.1016/j.jocrd.2017.09.002

Oliver, M. B., Kalyanaraman, S., Mahood, C., \& Ramasubramanian, S. (2007). Sexual and Violent Imagery in Movie Previews: Effects on Viewers' Perceptions and Anticipated Enjoyment. Journal of Broadcasting \& Electronic Media, 51(4), 596-614. https://doi.org/10.1080/08838150701626446

Otterson, J. (2019). ‘Game of Thrones’ Season 8 Premiere Draws 17.4 Million Viewers Variety. Variety. https://variety.com/2019/tv/news/game-of-thrones-season-8-premiereratings-1203189678/

Park, J. H., \& Schaller, M. (2005). Does attitude similarity serve as a heuristic cue for kinship? Evidence of an implicit cognitive association. Evolution and Human Behavior, 26, 158170. https://doi.org/10.1016/j.evolhumbehav.2004.08.013

Rhodes, G., Chan, J., Zebrowitz, L. A., \& Simmons, L. W. (2003). Does sexual dimorphism in human faces signal health? Proceedings. Biological sciences, 270 Suppl 1(Suppl 1), S93S95. https://doi.org/10.1098/rsbl.2003.0023

Rodenhizer, K. A. E., \& Edwards, K. M. (2017). The impacts of sexual media exposure on adolescent and emerging adults' dating and sexual violence attitudes and behaviors: A critical review of the literature. Trauma, Violence, \& Abuse, 20(4), 439-452. https://doi.org/10.1177/1524838017717745

Roseman, I. J., Wiest, C., \& Swartz, T. S. (1994). Phenomenology, behaviors, and goals differentiate discrete emotions. Journal of Personality and Social Psychology, 67(2), 206-221.

Rozée, P. D. (1993). Forbidden or forgiven?: Rape in cross-cultural perspective. Psychology of Women Quarterly, 17(4), 499-514. https://doi.org/10.1111/j.1471-6402.1993.tb00658.x 
Rozin, P., \& Fallon, A. E. (1987). A perspective on disgust. Psychological Review, 94, 23-41. https://doi.org/10.1037/0033-295X.94.1.23

Saad, G. (2012). Nothing in popular culture makes sense except in the light of evolution. Review of General Psychology, 16(2), 109-120. https://doi.org/10.1037/a0027906

Schaller, M., Miller, G. E., Gervais, W. M., Yager, S., \& Chen, E. (2010). Mere visual perception of other people's disease symptoms facilitates a more aggressive immune response. Psychological Science, 21(5), 649-652.

https://doi.org/10.1177/0956797610368064

Schaller, M., Murray, D. R., \& Bangerter, A. (2015). Implications of the behavioural immune system for social behaviour and human health in the modern world. Philosophical Transactions of the Royal Society of London. Series B, Biological Sciences, 370(1669). https://doi.org/10.1098/rstb.2014.0105

Sear, R., \& Mace, R. (2008). Who keeps children alive? A review of the effects of kin on child survival. Evolution and Human Behavior, 29(1), 1-18. https://doi.org/10.1016/j.evolhumbehav.2007.10.001

Seth, P., Lang, D. L., Diclemente, R. J., Braxton, N. D., Crosby, R. A., Brown, L. K., Hadley, W., \& Donenberg, G. R. (2012). Gender differences in sexual risk behaviours and sexually transmissible infections among adolescents in mental health treatment. Sexual Health, 9(3), 240-246. https://doi.org/10.1071/SH10098

Sherman, G. D., \& Haidt, J. (2011). Cuteness and disgust: The humanizing and dehumanizing effects of emotion. Emotion Review, 3(3), 245-251. https://doi.org/10.1177/1754073911402396

Stevenson, R. J., Case, T. I., \& Oaten, M. J. (2011). Effect of self-reported sexual arousal on responses to sex-related and non-sex-related disgust cues. Archives of Sexual Behavior, 40(1), 79-85. https://doi.org/10.1007/s10508-009-9529-z 
Taboas, W., Ojserkis, R., \& McKay, D. (2015). Change in disgust reactions following cognitivebehavioral therapy for childhood anxiety disorders. International Journal of Clinical and Health Psychology, 15(1), 1-7. https://doi.org/10.1016/j.ijchp.2014.06.002

Thornhill, \& Gangestad. (1999). Facial attractiveness. Trends in Cognitive Sciences, 3(12), 452460. https://doi.org/10.1016/S1364-6613(99)01403-5

Trivers, R. (1972). Parental investment and sexual selection. In B. Campbell (Ed.) Sexual Selection and the Descent of Man (53-95). Aldine: Chicago.

Tybur, J. M., Frankenhuis, W. E., \& Pollet, T. V. (2014). Behavioral immune system methods: Surveying the present to shape the future. Evolutionary Behavioral Sciences, 8(4), 274283. https://doi.org/10.1037/ebs0000017

Tybur, J. M., Inbar, Y., Aarøe, L., Barclay, P., Barlow, F. K., Barra, M. de, Becker, D. V., Borovoi, L., Choi, I., Choi, J. A., Consedine, N. S., Conway, A., Conway, J. R., Conway, P., Adoric, V. C., Demirci, D. E., Fernández, A. M., Ferreira, D. C. S., Ishii, K., ... Žeželj, I. (2016). Parasite stress and pathogen avoidance relate to distinct dimensions of political ideology across 30 nations. Proceedings of the National Academy of Sciences, 113, 12408-12413. https://doi.org/10.1073/pnas.1607398113

Tybur, J. M., Lieberman, D., \& Griskevicius, V. (2009). Microbes, mating, and morality: individual differences in three functional domains of disgust. Journal of Personality and Social Psychology, 97(1), 103-122. https://doi.org/10.1037/a0015474

Tybur, J. M., Lieberman, D., Kurzban, R., \& DeScioli, P. (2013). Disgust: Evolved function and structure. Psychological Review, 120(1), 65-84. https://doi.org/10.1037/a0030778

Westermarck, E. (1921). The history of human marriage (Vol. 2). Macmillan.

White, A. E., Kenrick, D. T., \& Neuberg, S. L. (2013). Beauty at the ballot box: disease threats predict preferences for physically attractive leaders. Psychological Science, 24(12), 2429-2436. https://doi.org/10.1177/0956797613493642 
Zillmann, D., \& Weaver, J. B. (2006). Effects of prolonged exposure to gratuitous media violence on provoked and unprovoked hostile behavior. Journal of Applied Social Psychology, 29(1), 145-165. https://doi.org/10.1111/j.1559-1816.1999.tb01379.x 
Table 1: Descriptives and Zero-order correlations for age, gender, nationality, number of times of watching the show, number of siblings, and the General Disgust

Scale, and Vignettes.

\begin{tabular}{|c|c|c|c|c|c|c|c|c|c|c|c|c|c|c|c|c|c|c|c|}
\hline & $M$ & $S D$ & 1 & 2 & 3 & 4 & 5 & 6 & 7 & 8 & 9 & 10 & 11 & 12 & 13 & 14 & 15 & 16 & 17 \\
\hline 1. Age & 25.82 & 8.03 & & & & & & & & & & & & & & & & & \\
\hline 2. Gender & & & 0 & & & & & & & & & & & & & & & & \\
\hline 3. & & & 0.02 & 0.02 & & & & & & & & & & & & & & & \\
\hline Nationality & & & & & & & & & & & & & & & & & & & \\
\hline $\begin{array}{l}\text { 4. Whether } \\
\text { Seen }\end{array}$ & & & $-0.15^{* * *}$ & -0.07 & $0.1^{*}$ & & & & & & & & & & & & & & \\
\hline $\begin{array}{l}\text { 5. Times } \\
\text { Seen }\end{array}$ & 2.35 & 1.47 & $0.25^{* * *}$ & -0.02 & $-0.11^{*}$ & $-\overline{0.55^{* * * *}}$ & & & & & & & & & & & & & \\
\hline $\begin{array}{l}\text { 6. Opposite } \\
\text { sex Sibling }\end{array}$ & & & 0.07 & 0.02 & $-0.1^{*}$ & -0.04 & $\begin{array}{l}0.11 \\
*\end{array}$ & & & & & & & & & & & & \\
\hline $\begin{array}{l}\text { 7. Number } \\
\text { of opposite } \\
\text { sex Siblings }\end{array}$ & .91 & .95 & 0.05 & 0.01 & $-0.1^{*}$ & -0.03 & $0.1^{*}$ & $0.77^{* * *}$ & & & & & & & & & & & \\
\hline $\begin{array}{l}\text { 8. Moral } \\
\text { Vignettes }\end{array}$ & 37.05 & 8.46 & 0.01 & $0.17^{* * * *}$ & -0.09 & $0.1^{*}$ & $\begin{array}{l}- \\
0.07\end{array}$ & 0 & 0.04 & & & & & & & & & & \\
\hline $\begin{array}{l}\text { 9. Sexual } \\
\text { Vignettes }\end{array}$ & 35.96 & 8.19 & -0.08 & $0.17^{* * * *}$ & $-\overline{0.19^{* * *}}$ & $0.1^{*}$ & $\begin{array}{l}- \\
0.03\end{array}$ & $0.17^{* * *}$ & $0.17^{* * * *}$ & $0.54^{* * * *}$ & & & & & & & & & \\
\hline $\begin{array}{l}10 . \\
\text { Pathogen } \\
\text { Vignettes }\end{array}$ & 8.16 & 3.56 & 0.01 & 0 & 0.04 & -0.03 & $-\overline{0.02}$ & 0.04 & 0.05 & $0.18^{* * * *}$ & $0.18^{* * *}$ & & & & & & & & \\
\hline $\begin{array}{l}\text { 11. Total- } \\
\text { Vignettes }\end{array}$ & 81.17 & 15.72 & -0.03 & $0.18^{* * * *}$ & $-0.14^{* *}$ & $0.1^{*}$ & $\begin{array}{l}- \\
0.06\end{array}$ & $0.1^{*}$ & $0.12^{* *}$ & $0.86^{* * *}$ & $0.85^{* * *}$ & $\begin{array}{l}0.42 * * \\
*\end{array}$ & & & & & & & \\
\hline $\begin{array}{l}\text { 12. Moral } \\
\text { Disgust }\end{array}$ & 30.94 & 9.57 & $0.15^{* * *}$ & 0 & 0 & $-0.12^{*}$ & 0.08 & 0.02 & 0.02 & $0.47^{* * *}$ & $0.25^{* * *}$ & $0.1^{*}$ & $0.41^{* * * *}$ & & & & & & \\
\hline $\begin{array}{l}\text { 13. Sexual } \\
\text { Disgust }\end{array}$ & 26.04 & 9.00 & 0.04 & $0.35^{* * *}$ & -0.09 & -0.03 & $\begin{array}{l}- \\
0.03\end{array}$ & 0.05 & 0.08 & $0.36^{* * *}$ & $0.41^{* * *}$ & $0.21^{* * * *}$ & $0.46^{* * *}$ & $0.29^{* * * *}$ & & & & & \\
\hline $\begin{array}{l}\text { 14. } \\
\text { Pathogen } \\
\text { Disgust }\end{array}$ & 31.19 & 8.54 & 0.03 & $0.1^{*}$ & $-{ }^{-} .17^{* * *}$ & $-{ }^{-} .19^{* * *}$ & 0.1 & 0.01 & 0.07 & $0.25^{* * * *}$ & $0.24^{* * *}$ & $0.35^{* * * *}$ & $0.34^{* * * *}$ & $0.33^{* * *}$ & $0.45^{* * * *}$ & & & & \\
\hline $\begin{array}{l}\text { 15. Total } \\
\text { Disgust }\end{array}$ & 88.17 & 20.45 & $0.1^{*}$ & $0.2^{* * *}$ & $-0.11^{*}$ & $-0.14^{* *}$ & 0.07 & 0.03 & 0.07 & $0.48^{* * * *}$ & $0.4^{* * *}$ & $0.28^{* * * *}$ & $0.53^{* * * *}$ & $0.73^{* * *}$ & $0.76^{* * * *}$ & $0.77^{* * * *}$ & & & \\
\hline $\begin{array}{l}\text { 16. Self- } \\
\text { Deceptive } \\
\text { Enhanceme } \\
n t\end{array}$ & 30.33 & 7.45 & $0.17^{* * *}$ & -0.08 & -0.01 & $-0.11^{*}$ & $\begin{array}{l}0.11 \\
*\end{array}$ & -0.05 & -0.06 & $-0.13^{* *}$ & -0.05 & -0.06 & $-0.11^{*}$ & 0.04 & 0.04 & 0.02 & 0.05 & & \\
\hline
\end{tabular}




\begin{tabular}{|c|c|c|c|c|c|c|c|c|c|c|c|c|c|c|c|c|c|c|c|}
\hline & $M$ & $\overline{S D}$ & 1 & 2 & 3 & 4 & 5 & $\overline{6}$ & 7 & 8 & 9 & 10 & 11 & 12 & 13 & 14 & 15 & 16 & 17 \\
\hline $\begin{array}{l}17 . \\
\text { Impression } \\
\text { Managemen }\end{array}$ & 31.73 & 8.21 & $0.25^{3 \ldots}$ & 0.05 & -0.04 & 0 & 0.02 & -0.02 & -0.03 & $0.12^{*}$ & $0.12^{* \prime \prime}$ & 0.01 & $0.13^{* *}$ & $0.24^{* * * *}$ & $0.2^{* * n+}$ & -0.04 & $0.18^{* * n+4}$ & $0.38^{*, *}$ & \\
\hline $\begin{array}{l}t \\
\text { 18. Social } \\
\text { Desirability }\end{array}$ & 62.06 & 12.99 & $0.26^{* * * *}$ & -0.01 & -0.04 & -0.07 & 0.08 & -0.04 & -0.05 & 0 & 0.05 & -0.03 & 0.02 & $0.17^{* * *}$ & $0.15^{* *}$ & -0.01 & $0.14^{* *}$ & $0.81^{* * *}$ & $0.85^{* * *}$ \\
\hline
\end{tabular}

Note: ${ }^{*} \mathrm{p} \leq .05,{ }^{* *} p \leq .01,{ }^{* * *} p \leq .001 ;$ Men $=1$, Women $=2$, Others $=3$; American $=1$, Indians $=2$, Others $=3$ 
Figure 1

$1 \mathrm{~A}$

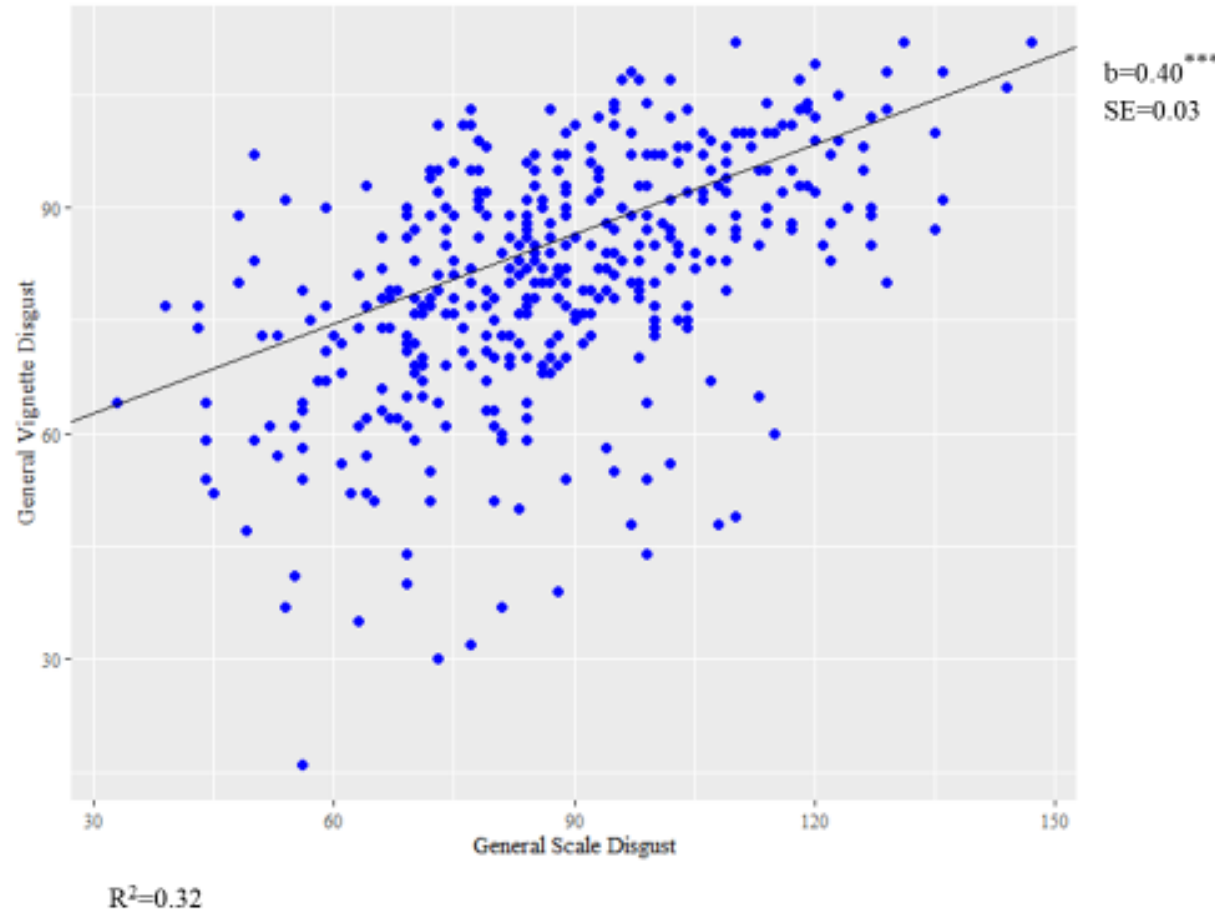

$1 \mathrm{~B}$ 
Among those who had seen the show at least once

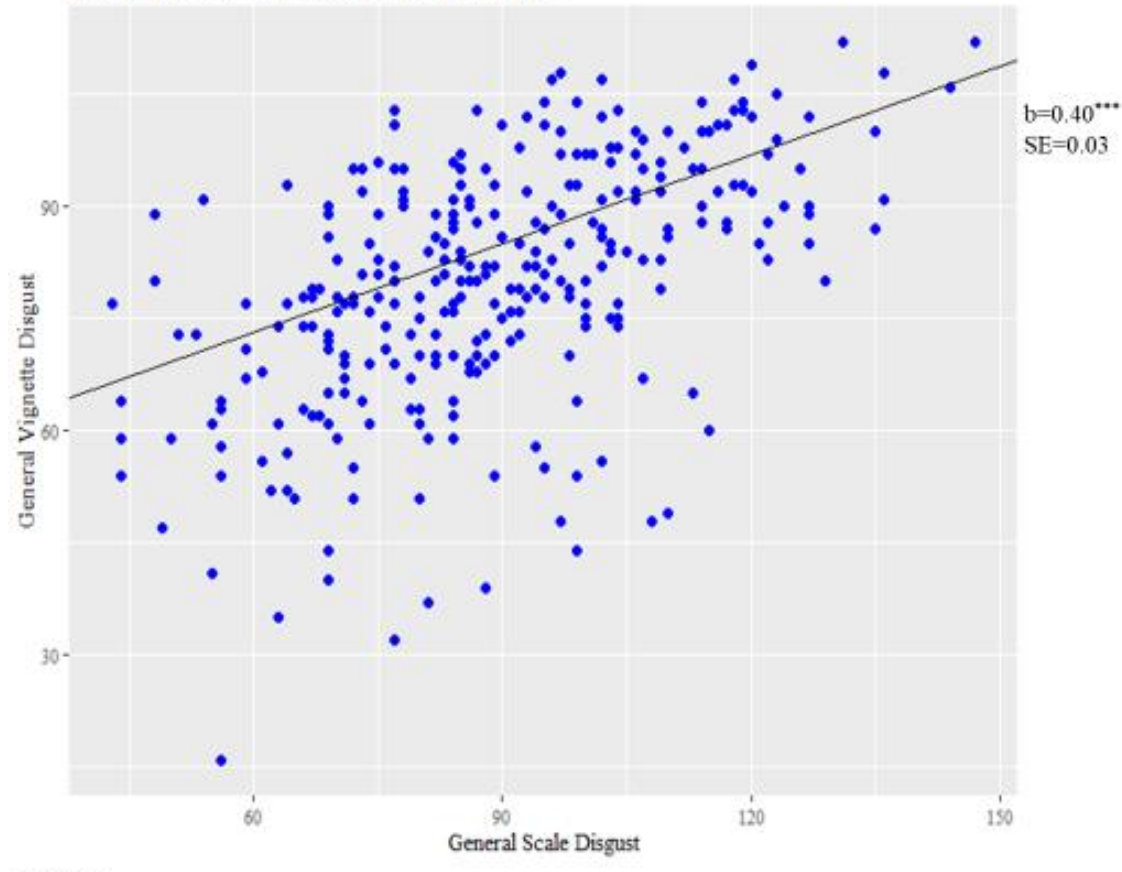

$\mathrm{R}^{2}=0.31$ 


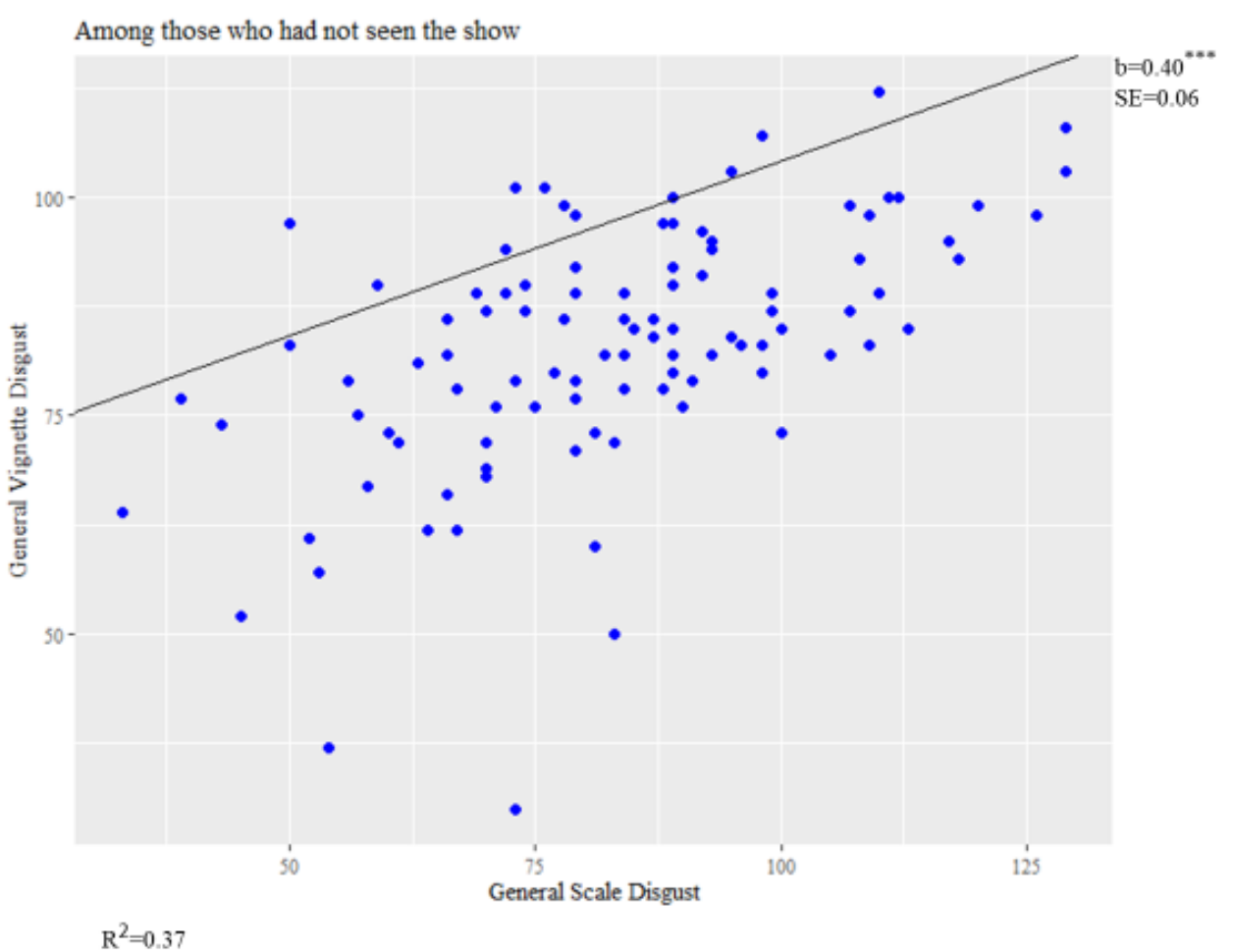

Figures $1 \mathrm{~A}-\mathrm{C}$ : The relationships between general trait disgust and general vignette disgust overall (1A), among those who had seen the show (1B), and those who had not (1C). 


\section{Appendix A: The Three Domain Disgust Scale}

Supplementary Table 1: Results of the t-test between Indians and Americans, Americans and Other Nationalities, and Indians and Other Nationalities on trait disgust sensitivity

\begin{tabular}{|c|c|c|c|c|c|c|c|c|c|c|c|c|c|c|c|c|}
\hline & \multicolumn{4}{|c|}{ Total Trait Disgust } & \multicolumn{4}{|c|}{ Moral Disgust } & \multicolumn{4}{|c|}{ Sexual Disgust } & \multicolumn{4}{|c|}{ Pathogen Disgust } \\
\hline & $\bar{M}$ & SD & $t^{0}$ & $d^{0}$ & $\bar{M}$ & $S D$ & $\bar{T}$ & $\bar{d}$ & $\bar{M}$ & $S D$ & $\bar{t}$ & $\bar{d}$ & $\bar{M}$ & $S D$ & $\bar{t}$ & $d$ \\
\hline Indians & 89.75 & 20.60 & .02 & 0.00 & 30.26 & 9.73 & $2.37 *$ & 0.27 & 26.64 & 8.99 & .23 & 0.03 & 32.84 & 8.52 & $2.32^{*}$ & 0.27 \\
\hline Americans & 89.71 & 19.39 & & & 32.74 & 8.71 & & & 26.41 & 8.53 & & & 30.56 & 8.68 & & \\
\hline Americans & 89.71 & 19.39 & $2.33^{*}$ & 0.31 & 32.74 & 8.71 & $2.39 *$ & 0.32 & 26.41 & 8.53 & 1.58 & 0.21 & 30.56 & 8.68 & 1.24 & 0.16 \\
\hline Others & 83.54 & 21.00 & & & 29.78 & 10.08 & & & 24.54 & 9.51 & & & 29.22 & 7.94 & & \\
\hline Indians & 89.75 & 20.60 & $2.41^{*}$ & 0.30 & 30.26 & 9.73 & .39 & 0.05 & 26.64 & 8.99 & 1.83 & 0.23 & 32.84 & 8.52 & $3.60^{* *}$ & 0.44 \\
\hline
\end{tabular}

Note: ${ }^{*} \mathrm{p} \leq .05 ;{ }^{* *} \mathrm{p} \leq .01 ;{ }^{0}$ The absolute values of Cohen's ds and $t$-values have been presented here. 

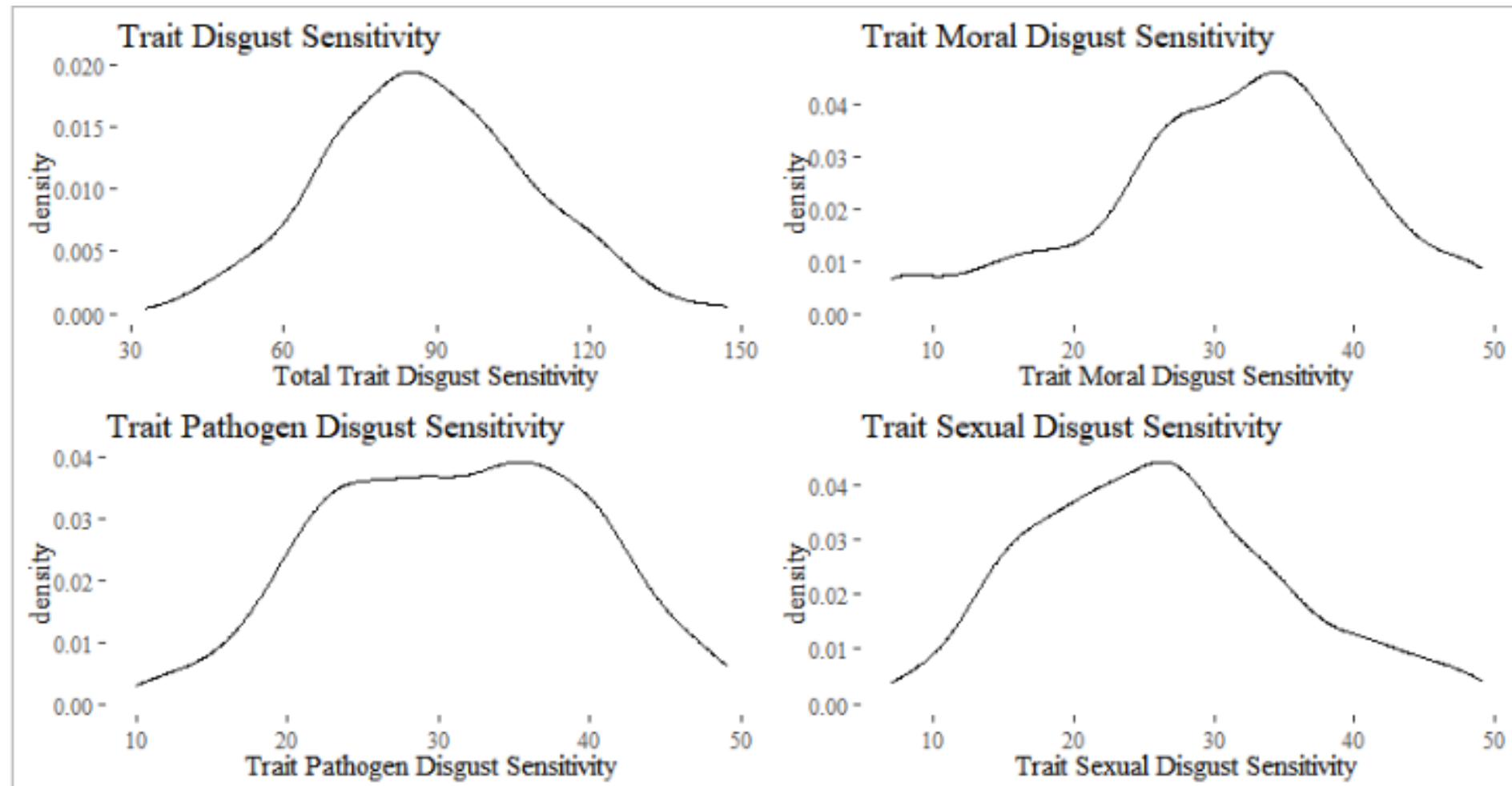

Supplementary Figure 1: Density Plots for general and specific trait disgust sensitivity. 


\section{Appendix B: Game of Thrones- Vignettes- EFA}

There was a significant difference in nationalities with respect the number of people who had seen versus not seen the show $\chi^{2}(\mathrm{df}=2, \mathrm{~N}=417)=7.64, \mathrm{p}<.001$., Cramer's $\mathrm{V}=.003$

Supplementary Table 2: Count of individuals who had watched and not watched, divided by nationality.

\begin{tabular}{lll|l}
\hline & Seen & Not Seen & Total \\
\hline Indians & 145 & 32 & 177 \\
Americans & 93 & 42 & 135 \\
Other Countries & 76 & 29 & 105 \\
\hline Total & 314 & 103 & 417 \\
\hline
\end{tabular}

\section{Exploratory Factor Analysis and Reliabilities}

A principal Axis Factoring (PAF) EFA was conducted as a data reduction method. For this, only the ratings by those who had seen the show were considered. A three-factor structure was assumed, based on previous literature, and accordingly, the direct oblimin method was used for oblique rotation, as the factors were theorized to correlate with each other. The three-factor solution explained $41.10 \%$ of the variance, where the first factor explained $28.74 \%$ of the variance, and the second factor explained $7.46 \%$, and the third explained $4.90 \%$.

Three other items (items v3, v12, and v14) had low loadings (i.e., below .3; Tybur et al., 2009) and therefore, they were excluded. The first factor involved items related to social transgressions, such as "Joffrey orders the execution of Ned Stark (at the end of Season 1), as punishment for a crime he didn't actually commit. This is done on the basis of the false confession of treason that Cersei acquires from Ned, in exchange of guarantee of Sansa's safety," and hence was included under moral disgust; the second factor involved items related to sexual disgust, such as "Cersei and Jamie are involved in a sexual relationship with each other;" and the third factor included items related to pathogen disgust, such as "Sam cures Ser Jorah's Greyscale by cutting off his pus-infected skin and applying herbal plasters to the openings." 
Three items (v4, v13 v15) cross-loaded with other factors. However, they were retained; v15 to retain third factor (pathogen disgust), and v4 and v13, after discussing with independent raters and because of importance of plot points in eliciting a disgust reaction.

A reliability analysis was done based on the three-factor structure. The internal consistencies for all four subscales were moderate to high (see Supplementary Table 2). 
Supplementary Table $3^{4}$ : Items and Factor Loadings of the Descriptions of Scenes depicted in Game of Thrones

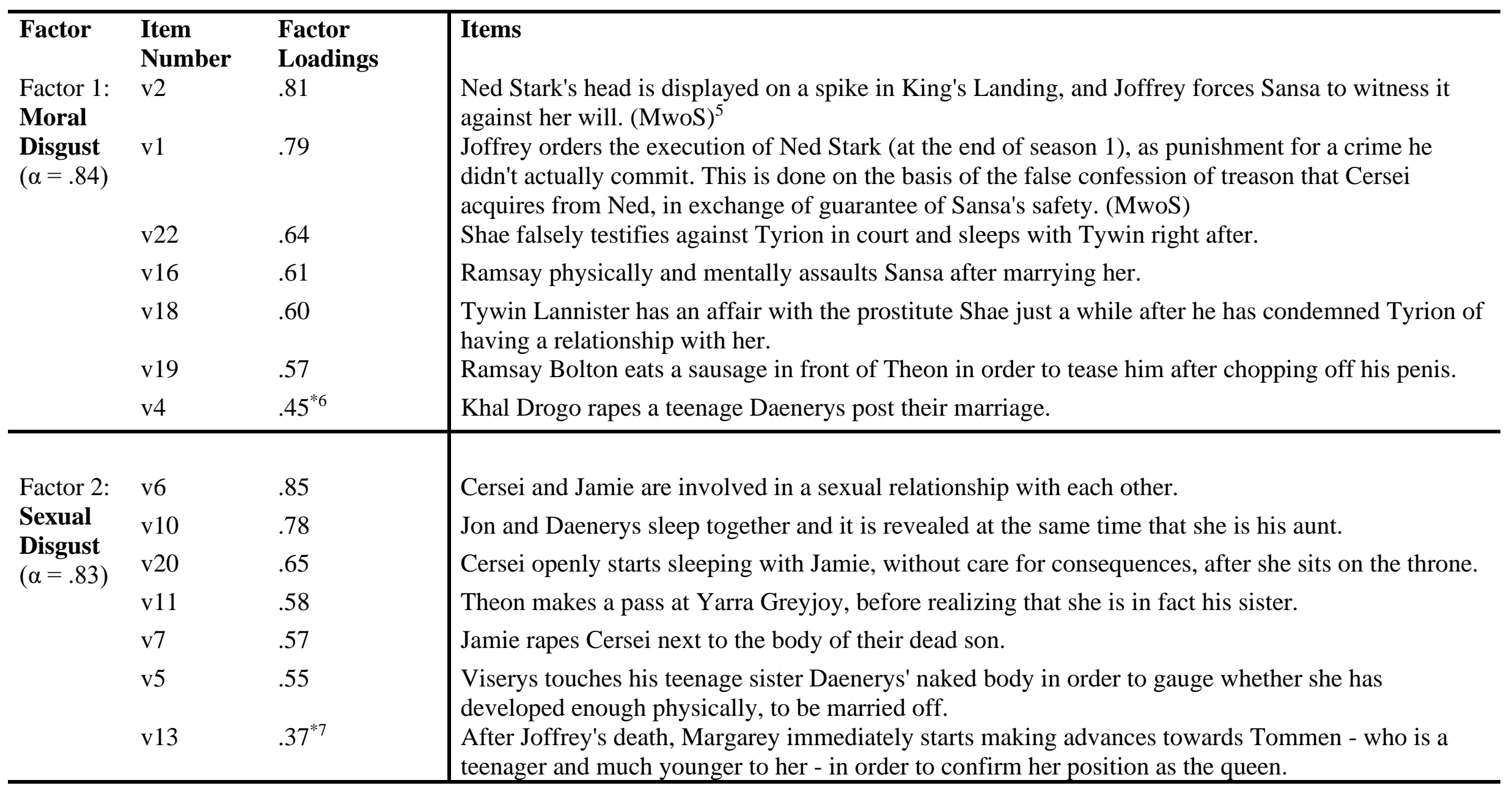

\footnotetext{
${ }^{4}$ Items are ordered and grouped by size of loading.

${ }^{5}$ Moral Disgust without sexual components.

${ }^{6}$ Item cross-loaded with Sexual Disgust

${ }^{7}$ Item cross-loaded with Moral Disgust
} 


\begin{tabular}{|c|c|c|c|}
\hline $\begin{array}{l}\text { Factor 3: } \\
\text { Pathoge } \\
\text { n } \\
\text { Disgust } \\
(\alpha=.65)\end{array}$ & v21 & .60 & $\begin{array}{l}\text { Sam cures Ser Jorah's Greyscale by cutting off his pus-infected skin and applying herbal plasters to } \\
\text { the openings. } \\
\text { Sam has to clean sick people's urinals and clothes, and assist in bodily autopsies. }\end{array}$ \\
\hline
\end{tabular}

Note: *Items that cross-loaded with other factors have been flagged.

Three items were deleted from this scale: "Robb Stark marries the woman of his choice, thereby betraying his promise to House Frey to marry one of their women" $(\lambda=.22)$; "Ramsay Bolton's hounds kill him by ripping him apart after sniffing the blood on his body ( $\lambda=.23)$; "Before dying, Lady Olenna tells Jamie to tell Cersei that she was instrumental in Joffrey's death" $(\lambda=.19)$. 


\section{Appendix C- Descriptions of Scenes}

For those who have seen the show

The following items describe various scenes of the show Game of Thrones. Please rate how disgusting you found the scenes described, where 0 means that you do not find the scene disgusting at all and 6 means that you find the scene extremely disgusting.

1. Joffrey orders the execution of Ned Stark (at the end of season 1), as punishment for a crime he didn't actually commit. This is done on the basis of the false confession of treason that Cersei acquires from Ned, in exchange of guarantee of Sansa's safety. Moral disgust. (Season 1, Episode 9)

2. Ned Stark's head is displayed on a spike in King's Landing, and Joffrey forces Sansa to witness it against her will. Moral disgust. (Season 1, Episode 10)

3. Robb Stark marries the woman of his choice, thereby betraying his promise to House Frey to marry one of their women. Moral disgust. (Season 2, Episode 10)

4. Khal Drogo rapes a teenage Daenerys post their marriage. Sexual disgust. (Season 1, Episode 1-2)

5. Viserys touches his teenage sister Daenerys' naked body in order to gauge whether she has developed enough physically, to be married off. Sexual disgust. (Season 1, Episode 1)

6. Cersei and Jamie are involved in a sexual relationship with each other. Sexual disgust. (Season 1, Episode 1)

7. Jamie rapes Cersei next to the body of their dead son. Sexual disgust. (Season 4, Episode 3)

8. Brienne of Tarth beats The Hound in combat. Filler. (Season 4, Episode 10)

9. Tyrion slaps Joffrey for being disrespectful. Filler. (Season 1, Episode 2)

10. Jon and Daenerys sleep together and it is revealed at the same time that she is his aunt. Sexual disgust. (Season 7, Episode 7)

11. Theon makes a pass at Yarra Greyjoy, before realizing that she is in fact his sister. Sexual disgust. (Season 2, Episode 2)

12. Ramsay Bolton's hounds kill him by ripping him apart after sniffing the blood on his body. Pathogen disgust. (Season 6, Episode 9)

13. After Joffrey's death, Margarey immediately starts making advances towards Tommen who is a teenager and much younger to her - in order to confirm her position as the queen. Sexual disgust. (Season 5, Episode 1)

14. Before dying, Lady Olenna tells Jamie to tell Cersei that she was instrumental in Joffrey's death. Moral Disgust (Season 7, Episode 3)

15. Sam has to clean sick people's urinals and clothes, and assist in bodily autopsies. Pathogen disgust. (Season 7, Episode 1) 
16. Ramsay physically and mentally assaults Sansa after marrying her. Sexual disgust. (Season 5, Episode 6) ${ }^{8}$

17. Arya insists that Ned get her a teacher for sword fighting. Filler. (Season 1, Episode 3)

18. Tywin Lannister has an affair with the prostitute Shae just a while after he has condemned Tyrion of having a relationship with her. Moral disgust. (Season 4, Episode 10)

19. Ramsay Bolton eats a sausage in front of Theon in order to tease him after chopping off his penis. Pathogen disgust. (Season 3, Episode 3)

20. Cersei openly starts sleeping with Jamie, without care for consequences, after she sits on the throne. Sexual disgust. (Season 7, Episode 3)

21. Sam cures Ser Jorah's Greyscale by cutting off his pus-infected skin and applying herbal plasters to the openings. Pathogen disgust. (Season 7, Episode 2)

22. Shae falsely testifies against Tyrion in court and sleeps with Tywin right after. Moral disgust. (Season 4, Episode 10)

23. Bran becomes the Three Eyed Raven. Filler. (Season 7, Episode 1)

For those who have not seen the show:

The following items describe various scenarios. Please rate how disgusting you found these scenarios, where 0 means that you do not find the scene disgusting at all and 6 means that you find the scene extremely disgusting.

1. A prince orders the execution of a noble lord, who was also his father's trusted friend (in the season 1 finale), as punishment for a crime he didn't actually commit. This is done on the basis of the false confession of treason that the prince's mother acquires from noble lord, in exchange of guarantee of the lord's daughter's safety. Moral disgust.

2. A noble lord's head is displayed on a spike at the capital, and the King forces the lord's daughter, who is also the King's betrothed to witness it against her will. Moral disgust.

3. A prince marries the woman of his choice, thereby betraying his promise to a loyal to marry one of their women. Moral disgust.

4. A man rapes his teenage wife post their marriage. Sexual disgust.

5. A man touches his teenage sister's naked body in order to gauge whether she has developed enough physically, to be married off. Sexual disgust.

6. Two opposite sex twins are involved in a sexual relationship with each other. Sexual disgust.

7. A brother rapes his sister next to the body of their dead son. Sexual disgust.

8. A woman beats a man in combat. Filler.

${ }^{8}$ This item was rated as both moral and sexual disgust. 
9. An uncle slaps his nephew for being disrespectful. Filler.

10. A man and a woman sleep together and it is revealed at the same time that she is his aunt. (They do not know of this) Sexual disgust.

11. A man makes a pass at a woman, before realizing that she is in fact his sister. Sexual disgust.

12. A man's hounds kill him by ripping him apart after sniffing the blood on his body. Pathogen disgust.

13. After a man's death, his wife immediately starts making advances towards his younger brother - who is a teenager and much younger to her - in order to confirm her position as the queen. Sexual disgust.

14. Before dying, an old woman tells a man to tell a woman that she was instrumental in their son's death.

15. A man has to clean sick people's urinals and clothes, and assist in bodily autopsies. Pathogen disgust.

16. A man physically and mentally assaults a woman after marrying her. Sexual disgust.

17. A young girl insists that her father get her a teacher for sword fighting. Filler.

18. A man has an affair with a prostitute just a while after he has condemned his son of having a relationship with her. Moral disgust.

19. A man eats a sausage in front of another man in order to tease him after chopping off his penis. Pathogen disgust.

20. A queen openly starts sleeping with her twin without care for consequences, after she sits on the throne. Sexual disgust.

21. A man cures another man's infectious disease by cutting off his pus-infected skin and applying herbal plasters to the openings. Pathogen disgust.

22. A prostitute falsely testifies against her ex-lover in court and sleeps with his father right after. Moral disgust.

23. A boy discovers that he has magical powers with which he can see anything he wishes from the past, present, and future. Filler. 